\title{
A NOVEL APPROACH IN DESIGNING ENTERIC-COATED ANTIPLATELET DRUG FOR BYPASSING STOMACH AND GASTRIC IRRITATION
}

\section{SUGALI BANOOTH THIRUMALESH NAIK ${ }^{1}$, MUNUSWAMY PURUSHOTHAMAN², KOTHAPALLI BANOOTH CHANDRA SEKHAR ${ }^{3}$}

\begin{abstract}
${ }^{1}$ Department of Pharmaceutics, Research Scholar, JNTUA, Ananthapuramu, Andhra Pradesh, India. ${ }^{2}$ Department of Pharmaceutics, Scient Institute of Pharmacy, Hyderabad, Telangana, India. ${ }^{3}$ Department of Chemistry, Krishna University, Machilipatnam, Andhra Pradesh, India. Email: thirunaikatp@gmail.com
\end{abstract}

Received: 08 September 2020, Revised and Accepted: 08 October 2020

ABSTRACT

Objective: The innovative approach in this investigation is making an enteric-coated acetylsalicylic acid (ASA) for antiplatelet activity using a novel excipient.

Methods: A novel methodology used in making ASA tablets for tackling the stomach irritation of ASA, by including Plantago ovata seed mucilage as a tablet binder. ASA compatibility with P. ovata seed mucilage was judged by differential scanning calorimetry (DSC) and Fourier Transform Infrared (FTIR) studies. All tablets were prosecuted for flow properties, physicochemical constraints, and release.

Results: The enteric-coated tablets established no interface by FTIR and DSC lessons. All the tablets possessed physicochemical constraints. The ASA showed its opposition to discharge in the stomach (2 h) and errand in a basic buffer (within $45 \mathrm{~min}$ ).

Conclusions: The work revealed that with the help of $P$. ovata as a tablet binder will resolve the disputes connected to gastric irritation.

Keywords: Antiplatelet, Mucilage, Binder, Tablet, Irritation.

(C) 2020 The Authors. Published by Innovare Academic Sciences Pvt Ltd. This is an open access article under the CC BY license (http://creativecommons. org/licenses/by/4. 0/) DOI: http://dx.doi.org/10.22159/ajpcr.2020.v13i11.39669

\section{INTRODUCTION}

The investigation was to make a postponed release stable tablet acetylsalicylic acid (ASA) to achieve bioavailability and to reduce the risk of gastric irritation. A low dose of ASA (75 mg) prescribed for its antiplatelet activity [1]; additionally, ASA is extremely moisture subtle. A day dose of ASA is proposed to discharge the drug after some adjournment or after passing the stomach.

Prolonged use of ASA causes ulceration in the stomach. Some attempts were made for the prevention of this issue by the coadministration of proton pump inhibitors (PPIs). However, they conclude with the interactions of ASA with PPIs [2,3]. Hence, it is essential to resolve such matters, the authors made a pioneering effort to include some excipient which should deserve both the purposes of gastro shielding actions and must help in the formulation. By performing an extensive literature survey, the authors found Plantago ovata seed mucilage, which has gastroprotective activity with tablet binding assets [4-6].

In this investigation, the author used $P$. ovata seed mucilage as a binder during tablet granulation and compressed them to tablets.

\section{METHODS}

\section{Materials}

The materials ASA was gifted from Waksman Selman pharmaceutical Pvt. Ltd, P. ovata seeds purchased from the local market of Anantapur. Lactose, MCC, Magnesium stearate, Talc, Ethylcellulose, HPMC Phthalate, Dichloromethane, Water (for HPLC), o-Phosphoric acid, and Acetonitrile were of Qualigens, Fine chemicals, Mumbai

The equipment and their make we as given below.

Electronic weighing balance (Citizen, CY-104, Mumbai); Wurster - Fluid bed coater (G.P.C.G.1.1); Bin blender (Tapasya); Tapped density tester (Electro lab); Hot Air oven (Shital Scientific Industries); Compression machine
(Cadmach); Friabilator (Electro lab); Hardness tester-Pfizer (mLabsSE-276; Digital pH meter (Inolab); Digital Vernier Calipers (Mitutoyo 500-196-20); Dissolution test apparatus (Lab India); UV-Visible doublebeam Spectrophotometer (Shimadzu); Differential Scanning Calorimeter (Schimadzu-DSC-50); Fourier Transform Infrared (FTIR) (Perkin Elmer, spectrum-100); Stability chamber (Thermo lab); Microwave oven (CATA2R); and Scanning Electron Microscope (JSM 6100 JEOL)

\section{Methodology}

Preformulation studies

FTIR spectral analysis

The toning among ASA with $P$. ovata was done by mixing 2 mg of ASA mixed with $200 \mathrm{mg}$ of $\mathrm{KBr}$, compacted to pellet, and screened (400$4000 \mathrm{~cm}^{-1}$ ) with a resolution of $1 \mathrm{~cm}^{-1}$.

DSC study

DSC thermograms of ASA with P. ovata were docked with diffraction scanning calorimeter, by heating $10^{\circ} \mathrm{C} / \mathrm{min}$ with a range of $30-350^{\circ} \mathrm{C}$.

\section{Experimental methods}

Isolation of P. ovata seeds mucilage

The isolation was performed as described by Abdul et al., 2010 [7]. The $P$. ovata seeds were soaked in distilled water ( $\sim 20$ times) for 2 days, simmered for $10 \mathrm{~min}$ (for the liberation of mucilage). Later passed through a muslin cloth (marc detached), and the scum was collected. Acetone was included in an equal fraction (mucilage precipitates). Then, the mucilage was isolated and parched in an oven $\left(<60^{\circ} \mathrm{C}\right)$, crumpled, sieved (\# 80 mesh), weighed, and placed in a desiccator.

\section{Characterization of P. ovata seeds mucilage}

The extracted mucilage from the $P$. ovata seeds when assessed for their consistency, ash values, loss on drying, swelling index and $\mathrm{pH}$, and flow properties (for dried powder). The physicochemical, phytochemical, and flow constraints of $P$. ovata seed mucilage $[8,9]$. 
Table 1: Composition of various ASA tablets

\begin{tabular}{|c|c|c|c|c|c|c|c|c|c|}
\hline \multirow[t]{2}{*}{ Ingredient } & \multicolumn{9}{|c|}{ Formulation } \\
\hline & AST-1 & AST-2 & AST-3 & AST-4 & AST-5 & AST-6 & AST-7 & AST-8 & AST-9 \\
\hline Aspirin & 75 & 75 & 75 & 75 & 75 & 75 & 75 & 75 & 75 \\
\hline Lactose & 10 & 10 & 10 & 10 & 10 & 10 & 10 & 10 & 10 \\
\hline Plantago ovata mucilage & 5 & 10 & 15 & 20 & 25 & 30 & 35 & 40 & 45 \\
\hline Magnesium stearate & 2 & 2 & 2 & 2 & 2 & 2 & 2 & 2 & 2 \\
\hline Talc & 1 & 1 & 1 & 1 & 1 & 1 & 1 & 1 & 1 \\
\hline Weight of the tablet & 300 & 300 & 300 & 300 & 300 & 300 & 300 & 300 & 300 \\
\hline
\end{tabular}

ASA: Acetylsalicylic acid

Preparation of tablets

Preparation of ASA enteric-coated tablets

The enteric-coated tablets for delayed-release have these steps $[10,11]$.

Preparation of core tablet

The ingredients (Table 1) screened (\#40 mesh) and compressed to get ASA tablets.

Sub coating of ASA

The above tablets were water-proofed by sub coating (Tables 2).

Composition of enteric coat

The above-subcoated tablets were further coated with an enteric coating material (Table 3).

\section{Evaluation of tablets}

Pre-compression constraints

Bulk and tapped densities, Carr's index, Hausner's ratio, and angle of repose were judged for the tableting blend $[7,12,13]$.

\section{Post-compression constraints}

The compressed tablets should possess good physicochemical constraints, as described below [14-16].

Weight variation

The weight of 20 tablets was individually weighed, and the mean was calculated and the deviation was calculated.

Diameter and thickness

Ten accidentally tablets from every batch were logged for diameter using a Vernier caliper, and the average was documented.

\section{Hardness test}

Each tablet was solely kept between the jaws Pfizer tablet hardness tester and pushed till it infatuates, and the mean was recorded.

As the ASA tablets were enteric-coated, no need to perform the friability test.

\section{Disintegration test}

ASA enteric-coated tablets were placed in $0.1 \mathrm{M} \mathrm{HCl}$ (for $2 \mathrm{~h}$ ), later in 6.8 $\mathrm{pH}, \mathrm{PBS}$ for $30 \mathrm{~min}$, and observed for tablet crumbling [17].

\section{Uniformity of drug content}

Ten tablets of ASA were weighed, triturated in a mortar. A $\equiv 100 \mathrm{mg}$ of ASA was relocated to a $50 \mathrm{ml}$ volumetric flask, volume made to require with acetonitrile and formic acid (99:1), manually shaken, centrifuged at $3000 \mathrm{rpm}$ for $5 \mathrm{~min}$, and then diluted as essential. An aliquot of the diluted solution was introduced into a liquid chromatograph with a detector set at $230 \mathrm{~nm}$. The rejoinders were associated with the standard to find the quantity in mg of ASA content in the sample. Table 4 depicts the chromatographic arrangements for ASA assessment [18].

In vitro dissolution studies

The dissolution conditions for ASA, as explained (Table 5) [19].
Table 2: Sub coating for ASA tablets

\begin{tabular}{ll}
\hline Ingredient/tablet & Quantity \\
\hline Ethylcellulose & 2.5 \\
Isopropyl alcohol & q.s \\
Dichloromethane & q.s \\
\hline
\end{tabular}

ASA: Acetylsalicylic acid

Table 3: Enteric coating for ASA tablets

\begin{tabular}{ll}
\hline Ingredient/tablet & Quantity \\
\hline HPMC phthalate-55 & 1.40 \\
Triethyl citrate & 0.25 \\
Talc & 0.35 \\
Dichloromethane & q.s \\
Methanol & q.s \\
\hline
\end{tabular}

ASA: Acetylsalicylic acid

\section{RESULTS AND DISCUSSION}

The physicochemical, phytochemical, and micromeritic constraints of P. ovata seed mucilage, as depicted in Table 6.

\section{DSC studies}

The thermogram of ASA showed an endothermic peak at $130.22^{\circ} \mathrm{C}$, and it combined with excipient showed that a shift in thermogram was observed with a peak of $127.79^{\circ} \mathrm{C}$ (Fig. 1). These data confirm the impregnation of drugs with excipients used.

The FTIR spectra revealed that the characteristic peaks and stretches of ASA were found even in the blend, which indicate compatibility confirmations of ASA with excipients (Fig. 2).

The ASA blend showed an angle of repose, Carr's compressibility index, and Hausner ratio values $<30^{\circ}, 10 \%$, and 1.25 , respectively, which indicates the good flow properties (Table 7).

The tablets were subjected to uniformity of weight, hardness, thickness, and assay. The consequences of these censures unveiled nearly uniform thickness in all the formulations. The weights of all tablets were within the $\pm 5 \%$ and passed the uniformity of weight as per official requests. All the tablets showed sufficient strength or hardness $\left(>4 \mathrm{Kg} / \mathrm{cm}^{2}\right)$, representing physical strength for which required during handling and transport. The hardness is not an absolute gauge of strength. The entericcoated ASA tablets did not show any sign of disintegration in $0.1 \mathrm{M} \mathrm{HCl}$ for $2 \mathrm{~h}$ and disintegrated within $45 \mathrm{~min}(2700 \mathrm{~s}$ ) in $\mathrm{pH} 6.8$ buffer, which verify the enteric coating efficiency of ASA enteric-coated tablets.

An appreciable uniformity in ASA content was observed among different batches of tablets, and the $\%$ of drug content was more than 95\% (Table 8).

The enteric-coated ASA tablets were not shown any sign of dissolution in $0.1 \mathrm{M} \mathrm{HCl}$ for $2 \mathrm{~h}$ and $>75 \%$ dissolved within $45 \mathrm{~min}$ in $\mathrm{pH} 6.8$ 
buffer (Fig. 3), which reveals the firmness of the enteric coat on ASA tablets.

Table 4: The chromatographic conditions for the assessing ASA

\begin{tabular}{ll}
\hline Chromatographic conditions & Specification \\
\hline Apparatus & HPLC \\
Column & $\mathrm{C} 18,250 \times 4.6,5 \mu$ (Inertsil) \\
Wavelength $(\mathrm{nm})$ & 230 \\
Detector & $\mathrm{UV} / \mathrm{PDA}$ \\
Injection volume & $20 \mu \mathrm{l}$ \\
Flow rate & $1.5 \mathrm{ml} / \mathrm{min}$ \\
Sample cooler temp & Ambient $\left(25^{\circ} \mathrm{C}\right)$ \\
Run time & 10 min \\
Elution & Isocratic \\
\hline
\end{tabular}

ASA: Acetylsalicylic acid

Table 5: Dissolution conditions fused in the study

\begin{tabular}{ll}
\hline Description & Condition \\
\hline $\begin{array}{l}\text { Apparatus } \\
\text { Medium }\end{array}$ & $\begin{array}{l}\text { Dissolution apparatus USP type II (Paddle) } \\
0.1 \mathrm{~N} \mathrm{HCl} \text { for } 2 \mathrm{~h} \text { and then phosphate buffer }(\mathrm{pH} \mathrm{6.8}) \\
\text { for next } 45 \mathrm{~min} \\
900 \mathrm{ml}\end{array}$ \\
$\begin{array}{l}\text { Medium } \\
\text { volume }\end{array}$ & 100 \\
$\begin{array}{l}\text { Speed } \\
\text { Sampling }\end{array}$ & $30 \mathrm{~min} .1$ and $2 \mathrm{~h}($ in $0.1 \mathrm{~m} \mathrm{HCl}) ; 5,10,20,30,45$, \\
intervals & and $60 \mathrm{~min}(6.8 \mathrm{buffer})$ \\
Temperature & $37 \pm 0.5^{\circ} \mathrm{C}$ \\
\hline
\end{tabular}

Table 6: Physicochemical, phytochemical, and micromeritic constraints of Plantago ovata seed mucilage

\begin{tabular}{ll}
\hline Parameter tested & Observation \\
\hline Test & \\
Color & Pale yellow \\
Odor & Aromatic \\
Physicochemical evaluation & $3.691 \pm 0.01 \% \mathrm{w} / \mathrm{v}$ \\
Total ash & $1.525 \pm 0.01 \% \mathrm{w} / \mathrm{v}$ \\
Water-soluble ash & $2.168 \pm 0.01 \% \mathrm{w} / \mathrm{v}$ \\
Acid-insoluble ash & $4.058 \pm 0.02 \% \mathrm{w} / \mathrm{v}$ \\
Ethanol-soluble extractive & $4.241 \pm 0.01 \% \mathrm{w} / \mathrm{v}$ \\
Ether-soluble extractive & $2.028 \pm 0.02 \%$ \\
Loss on drying & $457.27 \pm 1.28$ \\
Swelling index & $7.6 \pm 0.1$ \\
pH & \\
Phytochemical evaluation & A purple ring at the junction \\
Carbohydrate test (Molisch test) & \\
Flow properties & $25.26 \pm 0.11^{\circ}$ \\
Angle of repose & $0.524 \pm 0.02$ \\
Bulk density & $0.566 \pm 0.01$ \\
Tapped density & $7.092 \pm 0.03$ \\
Carr's Index & $1.078 \pm 0.01$ \\
Hausner's ratio & \\
\hline Values in mean \pm S.D; $\mathrm{n}=3$ &
\end{tabular}

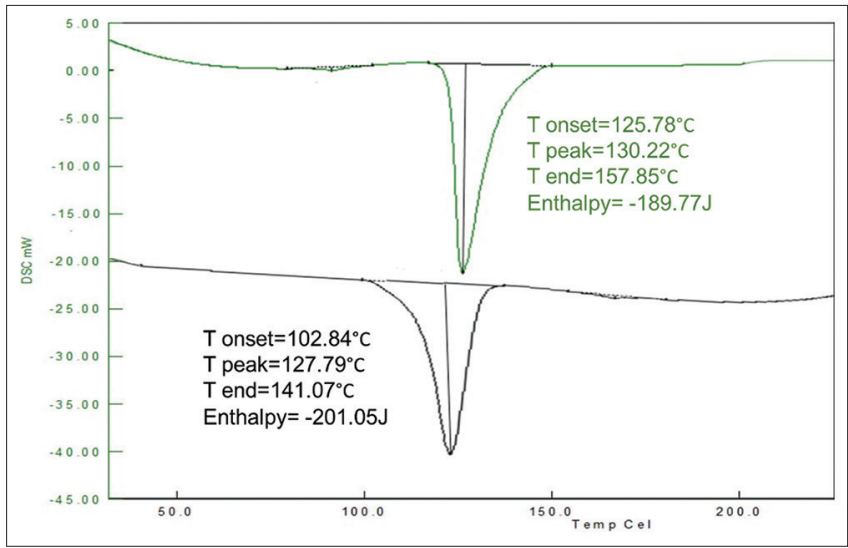

Fig. 1: Differential scanning calorimetry thermograms of acetylsalicylic acid and blend

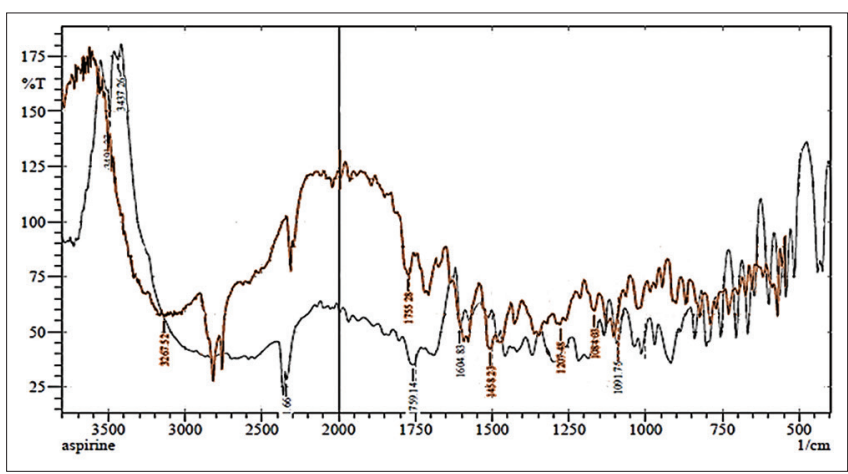

Fig. 2: Fourier transform infrared spectra of acetylsalicylic acid and its excipients

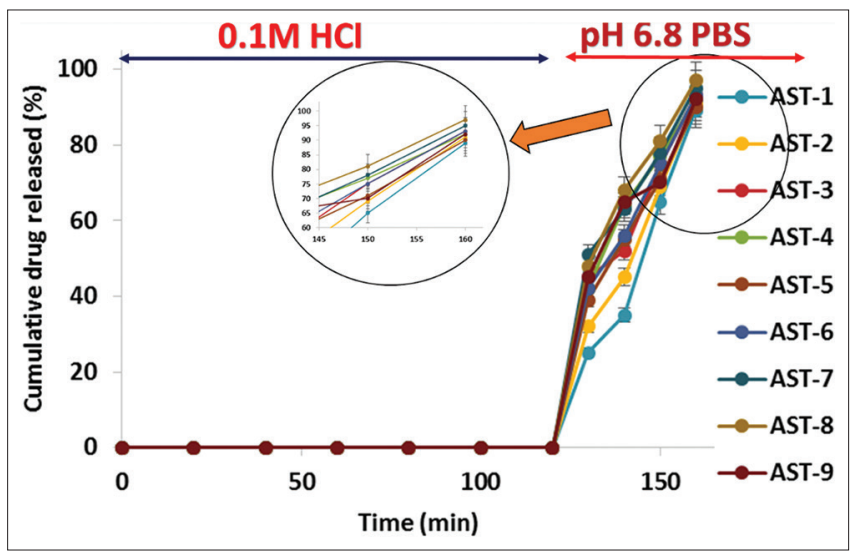

Fig. 3: Zero-order release plots for acetylsalicylic acid tablets

Table 7: Flow character specifications of ASA blend

\begin{tabular}{|c|c|c|c|c|c|}
\hline \multirow[t]{2}{*}{ Formulation } & \multicolumn{5}{|l|}{ Flow properties } \\
\hline & Angle of repose $\left(^{\circ}\right)$ & BD & TD & CI & HR \\
\hline AST-1 & $28.98 \pm 0.05$ & $0.528 \pm 0.01$ & $0.548 \pm 0.01$ & $3.649 \pm 0.02$ & $1.037 \pm 0.02$ \\
\hline AST-2 & $27.05 \pm 0.04$ & $0.635 \pm 0.02$ & $0.658 \pm 0.02$ & $3.495 \pm 0.06$ & $1.036 \pm 0.02$ \\
\hline AST-3 & $26.41 \pm 0.02$ & $0.519 \pm 0.01$ & $0.534 \pm 0.02$ & $2.808 \pm 0.05$ & $1.028 \pm 0.03$ \\
\hline AST-4 & $26.19 \pm 0.01$ & $0.456 \pm 0.02$ & $0.468 \pm 0.01$ & $2.564 \pm 0.08$ & $1.026 \pm 0.02$ \\
\hline AST-5 & $29.36 \pm 0.02$ & $0.625 \pm 0.01$ & $0.644 \pm 0.01$ & $2.950 \pm 0.07$ & $1.030 \pm 0.01$ \\
\hline AST-6 & $28.52 \pm 0.03$ & $0.635 \pm 0.02$ & $0.655 \pm 0.01$ & $3.053 \pm 0.02$ & $1.031 \pm 0.01$ \\
\hline AST-7 & $26.39 \pm 0.02$ & $0.546 \pm 0.01$ & $0.569 \pm 0.02$ & $4.042 \pm 0.05$ & $1.042 \pm 0.05$ \\
\hline AST-8 & $28.25 \pm 0.01$ & $0.682 \pm 0.01$ & $0.701 \pm 0.01$ & $2.710 \pm 0.01$ & $1.027 \pm 0.03$ \\
\hline AST-9 & $27.15 \pm 0.02$ & $0.567 \pm 0.01$ & $0.589 \pm 0.01$ & $3.735 \pm 0.06$ & $1.038 \pm 0.02$ \\
\hline
\end{tabular}

Values in mean \pm SD; trials $(n=3)$. ASA: Acetylsalicylic acid 
Table 8: Physical characteristics ASA tablets

\begin{tabular}{|c|c|c|c|c|c|c|}
\hline \multirow[t]{3}{*}{ Formulation } & \multicolumn{6}{|l|}{ Physical parameter } \\
\hline & \multirow[t]{2}{*}{ Uniformity of weight (mg) } & \multirow[t]{2}{*}{ Hardness $\left(\mathrm{cm}^{2}\right)$} & \multirow[t]{2}{*}{ Thickness (mm) } & \multicolumn{2}{|c|}{ Disintegration (s) } & \multirow[t]{2}{*}{ Assay (\%) } \\
\hline & & & & $0.1 \mathrm{M} \mathrm{HCl}(2 \mathrm{~h})$ & pH 6.8 & \\
\hline AST-1 & $300.04 \pm 1.00$ & $6.7 \pm 0.01$ & $3.02 \pm 0.04$ & 0.00 & $313 \pm 2$ & $97.82 \pm 4.11$ \\
\hline AST-2 & $301.20 \pm 1.60$ & $5.5 \pm 0.01$ & $3.01 \pm 0.03$ & 0.00 & $332 \pm 4$ & $99.83 \pm 8.95$ \\
\hline AST-3 & $300.28 \pm 1.94$ & $6.1 \pm 0.02$ & $2.98 \pm 0.03$ & 0.00 & $349 \pm 7$ & $96.73 \pm 2.43$ \\
\hline AST-4 & $301.98 \pm 2.01$ & $6.6 \pm 0.02$ & $3.00 \pm 0.03$ & 0.00 & $378 \pm 4$ & $97.06 \pm 4.65$ \\
\hline AST-6 & $302.50 \pm 1.68$ & $7.8 \pm 0.02$ & $3.01 \pm 0.01$ & 0.00 & $318 \pm 4$ & $98.48 \pm 2.05$ \\
\hline AST-7 & $300.39 \pm 1.09$ & $5.9 \pm 0.02$ & $3.01 \pm 0.02$ & 0.00 & $346 \pm 5$ & $98.09 \pm 1.29$ \\
\hline AST-8 & $299.32 \pm 2.07$ & $6.4 \pm 0.05$ & $2.99 \pm 0.04$ & 0.00 & $394 \pm 4$ & $98.46 \pm 2.04$ \\
\hline AST-9 & $300.09 \pm 1.25$ & $5.8 \pm 0.02$ & $3.01 \pm 0.02$ & 0.00 & $344 \pm 2$ & $99.95 \pm 2.36$ \\
\hline
\end{tabular}

Values in mean \pm SD; trials made $(n=3)$. ASA: Acetylsalicylic acid

\section{CONCLUSIONS}

The distinct enteric-coated ASA was effectively made with the inclusion of $P$. ovata seed mucilage as a tablet binder. The prepared tablets were devoid of any ulceration of the stomach as $P$. ovata it already proved for its gastric protective actions.

\section{ACKNOWLEDGMENTS}

The authors are thankful to USV Pvt. Ltd, Mumbai, and Waksman Selman pharmaceutical Pvt. Ltd, for providing gift sample of pure drug.

\section{CONFLICTS OF INTERESTS}

All the authors declare that they have no conflicting interests

\section{AUTHORS' CONTRIBUTIONS}

The authors announce together declares that all have contributed toward this research work. All the studies were conducted by all the authors together.

\section{AUTHORS' FUNDING}

Not applicable.

\section{REFERENCES}

1. Cox D, Maree AO, Dooley M, Conroy R, Byrne MF, Fitzgerald DJ. Effect of enteric coating on antiplatelet activity of low-dose aspirin in healthy volunteers. Stroke 2006;37:2153-8.

2. Adamopoulos AB, Sakizlis GN, Nasothimiou EG, Anastasopoulou I, Anastasakou E, Kotsi P, et al. Do proton pump inhibitors attenuate the effect of aspirin on platelet aggregation? A randomized crossover study. J Cardiovasc Pharmacol 2009;54:163-8.

3. Moayyedi P, Eikelboom JW, Bosch J, Connolly SJ, Dyal L, Shestakovska O, et al. Safety of proton pump inhibitors based on a large, multi-year, randomized trial of patients receiving rivaroxaban or aspirin. Gastroenterology 2019;157:682-91

4. Kota BP, Teoh AW, Roufogalis BD. Pharmacology of traditional herbal medicines and their active principles used in the treatment of peptic ulcer, diarrhoea and inflammatory bowel disease. New Adv Basic Clin Gastroenterol 2012;14:297-310.

5. Najafian Y, Hamedi SS, Farshchi MK, Feyzabadi Z. Plantago major in traditional persian medicine and modern phytotherapy: A narrative review. Electron Physician 2018;10:6390.
6. Al-Snafi AE. Arabian medicinal plants possessed gastroprotective effects-plant based review (Part 1). IOSR J Pharm 2018;8:77-95.

7. Ahad HA, Rajesh V, Gupta MV, Lasya DN, Harish N, Khamartaz M. Fabrication and in vitro evaluation of glimepiride Hibiscus esculentus fruit mucilage sustained release matrix tablets. Int $\mathrm{J}$ PharmTech Res 2010;2:78-83

8. Sepulveda ES, Saenz C, Aliaga E, Aceituno C. Extraction and characterization of mucilage in Opuntia spp. J Arid Environ 2007;68:534-45

9. Rodriguez-González S, Martínez-Flores HE, Chávez-Moreno CK, Macías-Rodríguez LI, Zavala-Mendoza E, Garnica-Romo MG, et al. Extraction and characterization of mucilage from wild species of Opuntia. J Food Process Eng 2014;37:285-92.

10. Tirpude RN, Puranik PK. Rabeprazole sodium delayed-release multiparticulates: Effect of enteric coating layers on product performance. J Adv Pharm Technol Res 2011;2:184.

11. Maraie NK, Alhamdany AT, Mahdi ZH. Application of the new oroslippery technology in the preparation of enteric slippery coated tablet of naproxen. Int J Pharm Pharm Sci 2017;9:198-204.

12. Abdul HA, Kumar CS, Kumar K. Designing and evaluation of diclofenac sodium sustained release matrix tablets using Hibiscus rosasinensis leaves mucilage. Int J Pharm Sci Rev Res 2010;1:29-31.

13. Shatla M, Kerk C, Altan T. Process modeling in machining. Part I: Determination of flow stress data. Int J Mach Tools Manuf 2001;41:1511-34.

14. Hindustan AA, Anuradha CM, Kumar CS, Reddy KK, Jagadeesh KD. Novel approach in formulation and evaluation of mouth dissolving tablets of ondansetron hydrochloride. Int J Appl Biol Pharm Technol 2010;1:582-8.

15. Ahad HA, Ravoori S, Buddideti KK, More S, Guddeti S, Patil VK. Fabrication and in vitro evaluation of gliquidone matrix tablets with Abelmoschus esculentus fruit mucilage and povidone combination. Acta Pharm Sci 2011;53:77-87.

16. Jeganathan B, Prakya V. Preparation and evaluation of floating extended release matrix tablet using combination of polymethacrylates and polyethylene oxide polymers. Int J Pharm Pharm Sci 2014;6:584-92.

17. Corá LA, Romeiro FG, Américo MF, Oliveira RB, Baffa O, Stelzer M, et al. Gastrointestinal transit and disintegration of enteric coated magnetic tablets assessed by ac biosusceptometry. Eur J Pharm Sci 2006;27:1-8.

18. An K, Ayyappan T, Raman VR, Vetrichelvan T, Sankar AS, Nagavalli D. RP-HPLC analysis of aspirin and clopidogrel bisulphate in combination. Indian J Pharm Sci 2007;69:597.

19. Islam A, Yasin T, Bano I, Riaz M. Controlled release of aspirin from $\mathrm{pH}-\mathrm{sensitive} \mathrm{chitosan/poly} \mathrm{(vinyl} \mathrm{alcohol)} \mathrm{hydrogel.} \mathrm{J} \mathrm{Appl} \mathrm{Polym} \mathrm{Sci}$ 2012;124:4184-92. 